\title{
Heavy metals concentration and pollution index (HPI) in drinking water along the southwest coast of Ghana
}

\author{
Regina Appiah-Opong ${ }^{1} \cdot$ Amoako Ofori $^{2} \cdot$ Mark Ofosuhene $^{1} \cdot$ Ebenezer Ofori-Attah $^{1} \cdot$ Francis K. E. Nunoo $^{3}$. \\ Isaac Tuffour ${ }^{1}$. Christopher Gordon ${ }^{2}$. Daniel K. Arhinful ${ }^{4}$. Alexander K. Nyarko ${ }^{1,5} \cdot$ Benedicta Y. Fosu-Mensah $^{2}$ (I)
}

Received: 24 June 2020 / Accepted: 25 February 2021 / Published online: 15 March 2021

(c) The Author(s) 2021

\begin{abstract}
The concentration of seven heavy metals in water samples was analyzed along the southwest coast of Ghana in the wet and dry seasons using atomic absorption spectrophotometer. Some physicochemical properties of the water samples were also determined to assess the quality of the water. The ranges of metal concentration in water in the wet season were; As

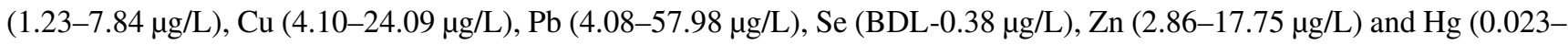
$0.068 \mu \mathrm{g} / \mathrm{L})$, whereas the ranges of metal concentration in the dry season were; As $(2.30-5.78 \mu \mathrm{g} / \mathrm{L}), \mathrm{Pb}(25.47-70.73 \mu \mathrm{g} / \mathrm{L})$, Se $(0.081-0.158 \mu \mathrm{g} / \mathrm{L}), \mathrm{Zn}(0.79-22.80 \mu \mathrm{g} / \mathrm{L})$ and $\mathrm{Hg}(0.004-0.047 \mu \mathrm{g} / \mathrm{L})$. The results of physicochemical properties of water in the wet season were $\mathrm{pH}(6.83$ to 7.52$)$, EC (291.15-780.64 $\mu \mathrm{S} / \mathrm{cm})$, TDS (195.07-523.02 mg/L), DO (2.98-4.39 mg/L), BOD $(3.33$ to $6.84 \mathrm{mg} / \mathrm{L})$, salinity $(0.01$ to $0.30 \mathrm{ppt})$ and temperature $\left(27.06-30.94{ }^{\circ} \mathrm{C}\right)$, whereas the dry season recorded the ranges of $\mathrm{pH}(6.84-6.95)$, EC (516.83 to $660.67 \mu \mathrm{S} / \mathrm{cm})$, TDS (307.07-442.65 mg/L), DO (1.71-3.04 mg/L), BOD $(4.25-13.38 \mathrm{mg} / \mathrm{L})$, salinity $(0.22-0.28 \mathrm{ppt})$ and temperature $\left(28.46-30.44{ }^{\circ} \mathrm{C}\right)$. The results showed that the concentration of heavy metals in water was below the WHO standard except $\mathrm{Pb}$ which exceeded the limit. The mean heavy metal pollution index (HPI) were 130 and 143 for wet and dry seasons, respectively, indicating that the water HPI was above the critical limit (HPI > 100), hence unfit for drinking. All the physicochemical properties analyzed were within the WHO permissible limits except BOD.
\end{abstract}

Keywords Water quality $\cdot$ Heavy metals $\cdot$ Southwestern Ghana $\cdot$ Lead and pollution index

Benedicta Y. Fosu-Mensah

yayramensah@staff.ug.edu.gh

1 Department of Clinical Pathology, Noguchi Memorial Institute for Medical Research, College of Health Sciences, University of Ghana, P.O. Box LG 581, Legon, Accra, Ghana

2 Institute for Environment and Sanitation Studies, College of Basic and Applied Sciences, University of Ghana, P.O. Box 209, Legon, Accra, Ghana

3 Department of Marine and Fisheries Sciences, School of Biological Sciences, College of Basic and Applied Sciences, University of Ghana, P.O. Box LG 99, Legon, Accra, Ghana

4 Department of Epidemiology, Noguchi Memorial Institute for Medical Research, College of Health Sciences, University of Ghana, P.O. Box LG 581, Legon, Accra, Ghana

5 School of Pharmacy, College of Health Sciences, University of Ghana, P.O. Box KB 52, Legon, Accra, Ghana

\section{Introduction}

Water quality is essential to the well-being and nourishment of water system, and it is one of the important functional components of the terrestrial ecosystem. The qualities of these water bodies vary widely depending on location and environmental factors. Water quality is defined in terms of chemical, physical and biological content, and the quality changes with season and geographic area. Groundwater is an important source of drinking water in many rural areas and plays an important role in the socioeconomic development of the country (Yankey et al. 2011). The presence of heavy metals in the environment is widespread as a result of both natural and anthropogenic activities and living organism are exposed to them through various pathways (Wilson and Pyatt 2007). Heavy metals are chemical elements with a specific gravity that is at least four to five times the specific gravity of water at the same temperature and pressure (Duruibe et al. 2007;

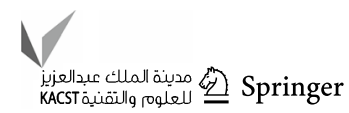


Obodai et al. 2011). They are among the most common environmental pollutants, and their occurrence in water, sediments and biota is as a result of inputs from natural or anthropogenic sources which may include domestic effluents and sewage, atmospheric deposition through rainfall, gas flaring, bush burning, fossil fuel combustion, paints (He et al. 2005). Urbanization and industrialization are one of the main indices of national and global development, but sometimes, while it enhances the quality of life, it also poses serious threats to the management of the natural ecosystem and public health (Umoren and Onianum 2005). Evaluation and understanding of the sources and impacts of the effects of heavy metals and physicochemical parameters of water is important for effective water management and preservation of water sources. The assessment of water quality is therefore a vital tool to manage water resources within a particular catchment.

The objective of the study was to assess the seasonal variability in the concentration of heavy metals and the physicochemical parameters of the sources of drinking water along the southwest coast of Ghana near the Jubilee Oil Field in the western region of Ghana.

\section{Materials and methods}

\section{The study area}

The study was conducted in four districts along the southwest coast of Ghana near the Jubilee Oil Field in the Western Region of Ghana. Four communities were selected as the study sites, in each district. The study communities were Atuabo in Ellembelle district, Half Assini in Jomoro district, Lower Axim in Nzema East municipality and Lower Dixcove in Ahanta West district (Fig. 1). The Western Region of Ghana covers an area of $23,921 \mathrm{~km}^{2}$, which forms about $10 \%$ of Ghana's total land size. It is located in the southwestern part of the country which lies between $5^{\circ} 23^{\prime} 24.7128^{\prime \prime} \mathrm{N}$ and $2^{\circ} 8^{\prime} 42.0864^{\prime \prime}$. It is bordered on the west by Ivory Coast, to the east by Central Region, on the north by Ashanti and Brong Ahafo Region and on the south by Gulf of Guinea. The total population of the region is 2,376,031 representing 9.6\% (Ghana Statistical Service 2010). The region has about $75 \%$ of its vegetation within the high forest zone of Ghana. The southwestern part of the region is noted for rainforest, interspersed with patches of mangrove forest along the coast and coastal wetlands. Tropical dense forest and

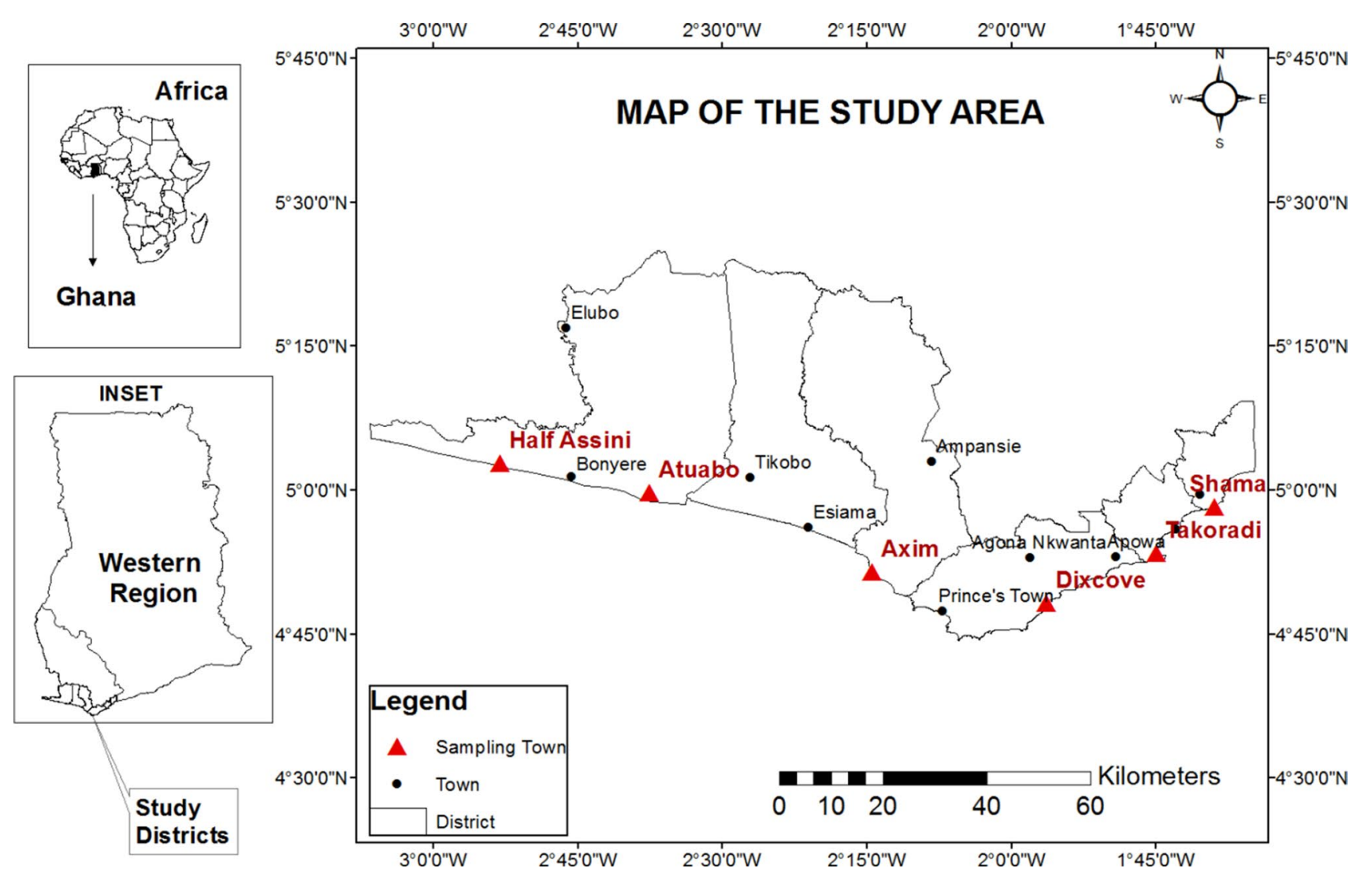

Fig. 1 Map of the study area 
semideciduous forest are also found in the northern part of the region. The region lies in the equatorial climatic zone characterized by moderate temperatures from 22 to $34{ }^{\circ} \mathrm{C}$ at night and day, respectively. The region is the wettest part of Ghana, with a bimodal rainfall pattern averaging $1,600 \mathrm{~mm}$ per year. The two rainfall peaks fall between May to July and September to October. The region also experiences intermittent minor rains all year round. The humidity of the region ranges from 70 to $90 \%$ (https://www.ghanadistricts.com).

\section{Sample collection, preparation and analytical procedures}

Water samples were collected from 20 different sampling points in the four districts in October 2014 and March 2015 for the wet and dry seasons, respectively. At each site, five water samples were collected into a $500-\mathrm{mL}$ plastic bottle which was washed and soaked in $10 \%$ nitric acid for $24 \mathrm{~h}$, rinsed thoroughly with double distilled water and oven-dried (APHA 2005). The water samples for heavy metal analysis were acidified with $0.5 \%$ nitric acid $\left(\mathrm{HNO}_{3}\right)$ to a $\mathrm{pH}$ below 2.0. Water samples were acidified to minimize the precipitation and adsorption of metals on the walls of the container (Sharma and Tyagi 2013) as well as to prevent microbial activity (Serfor-Armah et al. 2006). All the samples were well labeled and stored in an ice chest at $4{ }^{\circ} \mathrm{C}$ and transported to the Ecological Laboratory of University of Ghana for analysis. Water quality parameters such as temperature, $\mathrm{pH}$, electrical conductivity, total dissolved solids, salinity and dissolved oxygen were measured in situ. Temperature, $\mathrm{pH}$, electrical conductivity and salinity were measured using Horiba Digital Water Quality Checker (model U-50). The total dissolved solids (TDS) and dissolved oxygen (DO) were measured using OAKTON ${ }^{\circledR}$ PCD650. The probe end of the meter was dipped into the water samples to measure each parameter. The electrode of the meter was rinsed with distilled water after each sample measurement. Water samples were also collected into a dark airtight glass bottle for biochemical oxygen demand after five days of sampling. Water quality parameters were analyzed using standard procedures (APHA 2005). The concentration of heavy metals was measured using PINAAcle 900 T Perkin Elmer Atomic Absorption Spectrophotometer.

\section{Assessment of water contamination}

Contamination status of water samples was determined using the heavy metal pollution index (HPI). Pollution index was used to determine the combined effect of each heavy metal on the overall water quality (Reza and Singh 2010) and in order to assess the suitability for human consumption (Rizwan et al. 2011).
The HPI represents the total quality of water with respect to heavy metals, and it is calculated by assigning a weightage $\left(W_{i}\right)$ for individual parameter which is a value between 0 and 1 reflecting the relative importance of the individual quality consideration. This study used the WHO standards permissible value for drinking water.

The HPI was calculated using the following equation (Mohan et al. 1996; Milivojević et al. 2016; Chiamsathit et al. 2020):

$\mathrm{HPI}=\frac{\sum_{i=1}^{i=n}\left(Q_{i} \times W_{i}\right)}{\sum_{i=1}^{i=n} W_{i}}$

where $Q_{i}$ is the subindex of the $i$ th parameter, $W_{i}$ is the unit weight of the $i$ th parameter and $\mathrm{n}$ is the number of parameters considered; the subindex $\left(Q_{i}\right)$ of the parameter is

$Q_{i}=\frac{v_{i}}{s_{i}} \times 100$

where $V_{i}$ is the monitored value of metal of $i$ th parameter and $S_{i}$ the standard value.

The HPI value of drinking water less than 100 is classified as suitable for drinking (Balakrishnan and Ramu 2016).

\section{Data analysis}

Data obtained were analyzed using SPSS 20.0 version. Descriptive statistics were used to interpret the obtained data. One-way analysis of variance was used to test the difference between the sampling sites, and $t$ test was used to test the differences between the wet and dry seasons. Differences were considered significant at $p<0.05$. Pearson's correlation coefficient test (two-tailed) was used to establish the relationship between the concentration of heavy metals and physicochemical properties of the water samples.

\section{Results and discussions}

\section{Physicochemical parameters analyzed}

Results of the physicochemical parameters of water sampled analyzed during the wet and dry seasons are presented in Table 1 . The mean $\mathrm{pH}$ of water recorded in the dry season was not statistically different $(p>0.05)$ from the wet season. The results showed that significant differences $(p<0.05)$ were observed among the communities during the wet season but no significant differences $(p>0.05)$ were observed among the communities during the dry season. The $\mathrm{pH}$ values in the wet season ranged from 6.83 to 7.50 with a mean value of $7.17 \pm 0.24$, whereas the dry season ranged from 6.84 to 6.95 with a mean of $6.88 \pm 0.04$ (Table 1). The lowest 
Table 1 Physicochemical parameters of water samples during the wet and dry seasons

\begin{tabular}{llcccc}
\hline Parameter & Season & Min & Max & Mean \pm SD & $\begin{array}{l}\text { Standard } \\
\text { (WHO } \\
\text { 2011) }\end{array}$ \\
\hline pH & & & & & $6.5-8.5$ \\
& Wet & $6.83 \pm 0.39$ & $7.50 \pm 0.08$ & $7.17 \pm 0.24$ & $6.88 \pm 0.04$ \\
EC $(\mu \mathrm{S} / \mathrm{cm})$ & Dry & $6.84 \pm 0.06$ & $6.95 \pm 0.05$ & \\
& Wet & $291.15 \pm 196.05$ & $780.64 \pm 508.65$ & $491.84 \pm 402.80$ & 1000 \\
TDS $(\mathrm{mg} / \mathrm{L})$ & Dry & $516.83 \pm 199.53$ & $660.67 \pm 360.60$ & $574.29 \pm 498.70$ & \\
& Wet & $195.07 \pm 131.87$ & $523.02 \pm 340.80$ & $329.68 \pm 270$ & 1000 \\
DO $(\mathrm{mg} / \mathrm{L})$ & Dry & $307.07 \pm 374.26$ & $442.65 \pm 241.60$ & $364.90 \pm 274.60$ & \\
& Wet & $2.98 \pm 0.65$ & $4.39 \pm 0.92$ & $3.72 \pm 1.29$ & - \\
BOD $(\mathrm{mg} / \mathrm{L})$ & Dry & $1.71 \pm 0.40$ & $3.04 \pm 1.08$ & $2.48 \pm 0.09$ & \\
& Wet & $3.33 \pm 0.88$ & $6.84 \pm 4.85$ & $5.41 \pm 5.10$ & - \\
Salinity $(\mathrm{ppt})$ & Dry & $4.25 \pm 0.75$ & $13.38 \pm 2.27$ & $9.18 \pm 4.99$ & \\
& Wet & $0.10 \pm 0.06$ & $0.30 \pm 0.19$ & $0.18 \pm 0.14$ & \\
Temperature $\left({ }^{\circ} \mathrm{C}\right)$ & Wry & $0.22 \pm 0.08$ & $0.28 \pm 0.10$ & $0.27 \pm 0.24$ & \\
& Wet & $27.66 \pm 0.96$ & $30.94 \pm 3.38$ & $29.05 \pm 2.47$ & $22-29$ \\
& Dry & $28.46 \pm 1.17$ & $30.44 \pm 0.64$ & $29.23 \pm 1.44$ & \\
\hline
\end{tabular}

$\mathrm{pH}$ value was recorded at EA (site 1), while the highest was at $\mathrm{AD}$ (site 4) in the wet season. JH (site 1) and EA (site) recorded the lowest and highest values of $\mathrm{pH}$ during the dry season, respectively. The $\mathrm{pH}$ of the water was within the WHO (2004) permissible limit of 6.5-8.5 for drinking water. A pH value of water below 6.5 is regarded as acidic for human consumption because it can cause health issues such as acidosis and damage to the digestive and lymphatic system (Nkansah et al. 2010). At lower pH, the solubility of toxic metals in water increases which makes it harmful for consumption. According to Kim et al. (2002), the pH of this range may be attributed to the effects of bicarbonates, geology of the area and the buffering capacity of the water system. This result is in line with those reported by Koffi et al. (2014) and Mohamed and Zahir (2013) at Ivory Coast and India, respectively, but higher than the value 5.0 and 5.2 reported by Chiamsathit et al. (2020) from Thailand.

The values of electrical conductivity of water in the dry season were generally higher than the wet season; however, statistical analysis showed that the means were not different $(p>0.05)$ from each other. The mean EC values among the communities during the wet and dry seasons revealed that there were no significant differences $(p>0.05)$. The EC values in the wet season ranged from 291.15 to $780.64 \mu \mathrm{S} /$ $\mathrm{cm}$ with a mean of $491.84 \pm 402.80 \mu \mathrm{S} / \mathrm{cm}$, whereas the dry season ranged from 516.83 to $660.67 \mu \mathrm{S} / \mathrm{cm}$ (Table 1) with a mean of $574.29 \pm 498.70 \mu \mathrm{S} / \mathrm{cm}$. The lowest value of EC was recorded at EA (site 1) in the wet and dry seasons, whereas the highest was recorded at NL (site 3 ) for the wet and dry seasons. The results of electrical conductivity were below the WHO (2004) limit of $1000 \mu \mathrm{S} / \mathrm{cm}$ for drinking water. Although conductivity is not a human or aquatic health concern, it serves as an indication of other water quality problems (Dan et al. 2014). The high values of electrical conductivity recorded could be attributed to sea water intrusion because of its proximity to the ocean. The electrical conductivity values recorded in this study are similar to those found by Gyamfi et al. (2012) in some selected suburbs of Accra, Ghana.

Generally, the values of total dissolved solids in the dry season were higher than the wet season. However, the results of the wet season were not significantly different $(p>0.05)$ from the dry season. The mean values of TDS observed among the communities in wet and dry seasons were not significantly different $(p>0.05)$ from each other. The TDS in the wet season ranged from 195.07 to $523.02 \mathrm{mg} / \mathrm{L}$ with a mean value of $329.68 \pm 270 \mathrm{mg} / \mathrm{L}$, whereas the dry season ranged from 307.07 to $442.65 \mathrm{mg} / \mathrm{L}$ with a mean value of $364.90 \pm 274.6 \mathrm{mg} / \mathrm{L}$ (Table 1). The lowest value of TDS in the wet season was recorded at EA (site 1) and the highest at NL (site 3), while the dry season recorded the lowest value at JH (site 2) and the highest at NL (site 3). The TDS measured in all sites were below the WHO (2004) permissible limits of $1000 \mathrm{mg} / \mathrm{L}$. The TDS value of water close to $600 \mathrm{mg} / \mathrm{L}$ is acceptable, whereas those greater than $1000 \mathrm{mg} / \mathrm{L}$ are unpalatable for human consumption (Apau et al. 2014). According to WHO (1996), the concentration of TDS in water from natural sources varies from 30 to $600 \mathrm{mg} / \mathrm{L}$ depending on the solubility of minerals in the different geological regions. The results of TDS in this study are similar to those reported by Amfo-Out et al. (2012) at the Ga East Municipality of Ghana but higher than those reported by Chiamsathit et al. (2020) from Thailand.

The results of dissolved oxygen in the wet season were higher than the dry season. The DO showed no significant difference $(p>0.05)$ between the wet and dry seasons. The 
mean values of DO among the communities for both seasons were not different $(p>0.05)$ from each other. The wet season recorded DO values ranging from 2.98 to $4.39 \mathrm{mg} / \mathrm{L}$, whereas the dry season ranged from 1.71 to $3.04 \mathrm{mg} / \mathrm{L}$ (Table 1). The mean values of DO for the wet and dry seasons were $3.72 \pm 1.29$ and $2.48 \pm 0.89 \mathrm{mg} / \mathrm{L}$, respectively. The lowest value in the wet season was observed at NL (site 3 ) and the highest at EA (site 1). Additionally, AD (site 4) and $\mathrm{JH}$ (site 2) recorded the lowest and highest value of DO in the dry season, respectively. Dissolved oxygen (DO) in water is an important parameter in water analysis as it serves as an indicator of the physical, chemical and biological activities of the water body (Manikannan et al. 2011). The DO values measured were below the WHO standard of $7.5 \mathrm{mg} / \mathrm{L}$ for drinking water. The presence of high concentration of organic matter, dissolved gases and domestic effluents leaching into the water system decreases the oxygen content of water. The high salinity and temperature recorded in this study are known to affect the dissolution of oxygen (Manikannan et al. 2011). The DO values recorded in this study were lower than those reported by Garg et al. (2008) at Bharatpur area, India.

The biochemical oxygen demand of water was generally higher in the dry season than the wet season. The results of BOD in the wet season significantly differed $(p<0.05)$ from the dry season. However, statistical analysis revealed that the means of BOD among the communities in the wet and dry seasons were not different $(p>0.05)$ from each other. The BOD in the wet season ranged from 3.33 to $6.84 \mathrm{mg} / \mathrm{L}$ and 4.25 to $13.38 \mathrm{mg} / \mathrm{L}$ in the dry season (Table 1 ). The mean values of BOD for the wet and dry seasons were 5.41 \pm 5.10 and $9.18 \pm 4.99 \mathrm{mg} / \mathrm{L}$, respectively. EA (site 1) and NL (site 3 ) recorded the lowest and highest values of BOD, respectively, while EA (site 1) and AD (site 4) recorded the lowest and highest, respectively. According to Oluyemi et al. (2010), BOD values less than $6 \mathrm{mg} / \mathrm{L}$ suggest that the water is least polluted with organic matter.

The results of water salinity recorded in the dry season were generally higher than the wet season. However, there was no significant difference $(p>0.05)$ between the dry and the wet seasons. The results of water salinity among communities in the wet and dry seasons showed no statistical difference $(p>0.05)$. The values of salinity in the wet season ranged from 0.01 to $0.30 \mathrm{ppt}$ ) with a mean value of $0.18 \pm 0.14 \mathrm{ppt}$ and 0.22 to $0.28 \mathrm{ppt}$ in the dry season with a mean of $0.27 \pm 0.24 \mathrm{ppt}$ (Table 1). EA (site 1) and NL (site 3 ) recorded the lowest and highest value in the wet season, respectively, while $\mathrm{JH}$ (site2) and $\mathrm{AD}$ (site 4) recorded the lowest and highest in the dry season, respectively. The mean values of salinity recorded during the wet season were lower to the WHO limit of $200 \mathrm{mg} / \mathrm{L}$, whereas the dry season was higher than the permissible limit. The high level of salinity in the dry season may be attributed to high surface evaporation, low flow of water, decrease in water level and sea water intrusion (Dan et al. 2014). These results are contrary to those reported by Manikannan et al. (2011).

Results of water temperature in the dry season were higher than the wet season. However, there were no significant differences $(p>0.05)$ between the wet and dry seasons. No statistical difference $(p>0.05)$ was observed among the communities in the wet and dry seasons. Water temperature ranged from 27.66 to $30.94{ }^{\circ} \mathrm{C}$ with a mean value of $29.05 \pm 2.47^{\circ} \mathrm{C}$ in the wet season, whereas the dry season ranged from 28.46 to $30.44{ }^{\circ} \mathrm{C}$ with a mean value of $29.23 \pm 1.44{ }^{\circ} \mathrm{C}$. The minimum value was recorded at AD (site 4 ) and the maximum at EA (site 1) in the wet season, whereas the lowest and highest in the dry season were recorded at JH (site 2) and NL (site 3), respectively. Temperature may also be influenced by the depth of water, season, groundwater influx and air circulation as well as the time of sampling (Peirce et al. 1998). These results agree with those found by Koffi et al. (2014) in Ivory Coast.

\section{Heavy metals concentration in water samples}

Table 2 presents results of heavy metals concentration in water during wet and dry seasons. The wet season recorded the highest concentration of arsenic in water than the dry season. However, the mean concentration of arsenic showed no significant difference $(p>0.05)$ between the wet and dry seasons. Statistical difference $(p>0.05)$ was not observed among the communities during the wet and dry seasons. Arsenic in water ranged from 1.23 to $7.84 \mu \mathrm{g} / \mathrm{L}$ in the wet season and 2.30 to $5.78 \mu \mathrm{g} / \mathrm{L}$ in the dry season (Table 2). The mean concentration of arsenic in the wet and dry seasons was $3.66 \pm 2.50$ and $3.21 \pm 2.56 \mu \mathrm{g} / \mathrm{L}$, respectively. The wet season recorded the lowest and highest concentration of arsenic at JH (site 2) and EA (site 1), whereas the dry season recorded the lowest and highest at NL (site 3) and EA (site 1), respectively. The concentration of arsenic in groundwater at all the sampling sites was below the WHO (2011) permissible limit of $10 \mu \mathrm{g} / \mathrm{L}$. This result is contrary to those reported by Mukherjee et al. (2006) who found arsenic to be in the range of 1 to $64 \mu \mathrm{g} / \mathrm{L}$ at Obuasi and Bolgatanga in Ghana. The high concentration of arsenic in water was attributed to the presence of arsenopyrites and pyrites in the rock basement of the area. According to Bhattacharya et al. (2007), arsenic in groundwater has been detected in some countries which exceeded the WHO guideline value of $10 \mu \mathrm{g} / \mathrm{L}$.

Copper was not detected in all the water samples analyzed in the dry season. Statistical analysis reveals that there were significant differences $(p<0.05)$ among the communities in the wet season. Copper ranged from 4.10 to $24.09 \mu \mathrm{g} / \mathrm{L}$ with a mean value of $11.50 \pm 7.54$. The lowest concentration was recorded at $\mathrm{AD}$ (site 4), whereas $\mathrm{JH}$ (site2) recorded the 
Table 2 Heavy metals concentration of water samples during the wet and dry seasons

\begin{tabular}{|c|c|c|c|c|c|}
\hline Parameter & Season & Min & Max & Mean \pm SD & $\begin{array}{l}\text { Standard } \\
\text { (WHO } \\
2011)\end{array}$ \\
\hline \multirow[t]{2}{*}{ As $(\mu \mathrm{g} / \mathrm{L})$} & Wet & $1.23 \pm 0.27$ & $7.84 \pm 7.71$ & $3.33 \pm 2.50$ & \multirow[t]{2}{*}{10} \\
\hline & Dry & $2.30 \pm 2.18$ & $5.78 \pm 3.70$ & $3.21 \pm 2.56$ & \\
\hline \multirow[t]{2}{*}{$\mathrm{Cu}(\mu \mathrm{g} / \mathrm{L})$} & Wet & $4.10 \pm 2.01$ & $24.09 \pm 17.56$ & $11.50 \pm 7.54$ & \multirow[t]{2}{*}{2000} \\
\hline & Dry & - & - & - & \\
\hline \multirow[t]{2}{*}{$\mathrm{Pb}(\mu \mathrm{g} / \mathrm{L})$} & Wet & $40.88 \pm 7.75$ & $57.98 \pm 8.31$ & $47.67 \pm 6.76$ & \multirow[t]{2}{*}{10} \\
\hline & Dry & $25.47 \pm 13.95$ & $70.73 \pm 34.88$ & $70.73 \pm 34.88$ & \\
\hline \multirow[t]{2}{*}{$\mathrm{Se}(\mu \mathrm{g} / \mathrm{L})$} & Wet & $\mathrm{BDL}$ & $0.39 \pm 0.04$ & $0.22 \pm 0.14$ & \multirow[t]{2}{*}{40} \\
\hline & Dry & $0.08 \pm 0.07$ & $0.16 \pm 0.02$ & $0.12 \pm 0.03$ & \\
\hline \multirow[t]{2}{*}{$\mathrm{Zn}(\mu \mathrm{g} / \mathrm{L})$} & Wet & $7.12 \pm 1.34$ & $22.68 \pm 8.02$ & $15.44 \pm 5.89$ & \multirow[t]{2}{*}{3000} \\
\hline & Dry & $0.79 \pm 1.49$ & $22.80 \pm 24.20$ & $15.08 \pm 8.48$ & \\
\hline \multirow[t]{2}{*}{$\mathrm{Hg}(\mu \mathrm{g} / \mathrm{L})$} & Wet & $0.023 \pm 0.27$ & $0.068 \pm 0.50$ & $0.042 \pm 0.017$ & \multirow[t]{2}{*}{6} \\
\hline & Dry & $0.004 \pm 0.002$ & $0.047 \pm 0.037$ & $0.03 \pm 0.016$ & \\
\hline
\end{tabular}

highest concentration of copper. Copper enters the water system through mineral dissolution, domestic and industrial effluents or use of pesticides. The amount of copper detected in water at all sampling points was below the WHO permissible limit of $2000 \mu \mathrm{g} / \mathrm{L}$. Gyamfi et al. (2012) reported higher values of $\mathrm{Cu}$ ranging from 3 to $308 \mu \mathrm{g} / \mathrm{L}$ than those obtained in this study which was also below the guideline values. However, some amount of copper is required for metabolism and the synthesis of hemoglobin, myoglobin, cytochromes and several enzymes (Maughan 1999), whereas high consumption of copper may lead to neurological complications, hypertension, liver and kidney problems (Krishna and Govil 2004).

The results of water samples analyzed in the dry season showed a higher concentration of lead than the wet season. The wet and dry seasons showed no significant difference $(p>0.05)$ in the concentration of lead. The mean values of lead among the communities in the wet season showed no significant difference $(p>0.05)$ but statistical difference $(p<0.05)$ was observed among the communities in the dry season. Lead in water ranged from 40.88 to $57.98 \mu \mathrm{g} / \mathrm{L}$ in the wet season and 25.47 to $70.73 \mu \mathrm{g} / \mathrm{L}$ in the dry season (Table 2). The mean concentration of lead for the wet and dry seasons was $47.67 \pm 6.76$ and $53.06 \pm 17.01 \mu \mathrm{g} / \mathrm{L}$, respectively. The lowest concentration of lead was recorded at AD (site 4) and the highest at NL (site 3) in the wet season, whereas the lowest and highest were observed at AD (site 4) and JH (site 2), respectively, in the dry season. Lead naturally occurs in lead sulfide and other minerals. The concentration of lead in water at all sites exceeded the WHO (2011) permissible limits of $10 \mu \mathrm{g} / \mathrm{L}$. Hence, the consumption of water can pose a significant risk to the consumers. The findings of lead in water which ranged from 90 to $200 \mu \mathrm{g} / \mathrm{L}$ by Apau et al. (2014) were higher than those reported in this study. Lead is known to induce a broad range of physiological, biochemical and behavioral dysfunction in human and animals which affects the central and peripheral nervous system, hemopoietic system, cardiovascular system, kidney and liver (Hsu and Leon 2002).

Selenium in water was higher in the wet season than the dry season. Selenium showed significant difference $(p<0.05)$ between the wet and dry seasons. However, the wet season showed significant difference $(p<0.05)$ among the communities, but no statistical difference $(p>0.05)$ was observed among the communities in the dry season. Selenium in water ranged from below detection limit to $0.38 \mu \mathrm{g} / \mathrm{L}$ in the wet season and 0.081 to $0.158 \mu \mathrm{g} / \mathrm{L}$ in the dry season. The mean concentration of selenium for the wet and dry seasons was $0.22 \pm 0.14$ and $0.12 \pm 0.03 \mu \mathrm{g} / \mathrm{L}$, respectively. AD (site 4) and EA (site 1) recorded the lowest and highest concentration in the wet season, whereas EA (site 1) and AD (site 4) recorded the lowest and highest concentrations in the dry season, respectively. The amount of selenium in water at all sampling sites was below the WHO (2011) permissible limits of $40 \mu \mathrm{g} / \mathrm{L}$ although significant difference was observed between the wet and dry seasons.

The level of heavy metals concentration in water samples analyzed in the study area increases in the order of $\mathrm{Hg}<\mathrm{Se}<\mathrm{As}<\mathrm{Zn}<\mathrm{Cu}<\mathrm{Pb}$.

The concentration of zinc in water was higher in the wet season than the dry season. The mean concentration of zinc for the wet and dry seasons was not different $(p>0.05)$ from each other. All the samples analyzed in the wet and dry seasons showed no statistical difference $(p>0.05)$ among the communities. Zinc in water ranged from 7.12 to $22.60 \mu \mathrm{g} / \mathrm{L}$ with a mean value of $15.44 \pm 5.89 \mu \mathrm{g} / \mathrm{L}$. in the wet season and 0.79 to $22.80 \mu \mathrm{g} / \mathrm{L}$ with a mean value of $15.08 \pm 8.48 \mu \mathrm{g} / \mathrm{L}$ in the dry season (Table 2 ). The lowest and highest values of $\mathrm{Pb}$ in the wet season were recorded at NL (site 3) and EA (site 1), whereas NL (site 3) and JH 
(site 2) recorded the lowest and highest concentrations, respectively, in the dry season. Zinc is an essential element required by human for optimum growth and development. The WHO permissible limit of zinc in drinking water is $3000 \mu \mathrm{g} / \mathrm{L}$. The concentration of zinc fell below this limit, thus suitable for human consumption. Gyamfi et al. (2012) recorded mean values of $\mathrm{Zn}$ ranging from 108 to $1876 \mu \mathrm{g} / \mathrm{L}$ which was higher than those reported in this study but below the recommended limit. The presence of high amount of zinc in water may cause a bitter taste and opalescence in water.

The wet season recorded the highest concentration of mercury in water than the dry season. The results of mercury in water for the wet and dry seasons were not significantly different $(p>0.05)$ from each other. The mean concentration of mercury among the communities showed no significant difference $(p>0.05)$ for the wet and dry seasons. Mercury ranged from 0.023 to $0.068 \mu \mathrm{g} / \mathrm{L}$ in the wet season and 0.004 to $0.047 \mu \mathrm{g} / \mathrm{L}$ in the dry season. The mean concentrations of mercury in the wet and dry seasons were $0.042 \pm 0.017$ and $0.03 \pm 0.016$, respectively. EA (site 1) and JH (site 2) recorded the lowest and highest concentrations of mercury in the wet and dry seasons. Mercury is a naturally occurring metal which occurs in trace amount in water, soil and rocks. It is volatile in nature which is released into the atmosphere through natural degassing of the earth crust. The most important anthropogenic sources of mercury pollution in the environment are urban discharge, agricultural materials, mining, combustion and industrial discharge (Zhang and Wong 2007). Mercury content in water samples analyzed was below the WHO (2011) permissible limit of $6 \mu \mathrm{g} / \mathrm{L}$, hence suitable for consumption. Similar observations have been reported by Adjei-Kyereme et al. (2015) who found the concentration of $\mathrm{Hg}$ in water to be less than $1.0 \mu \mathrm{g} / \mathrm{L}$.

\section{Heavy metal pollution index (HPI) in water}

The mean values of heavy metal concentration recorded in the wet and dry seasons were used to calculate the heavy metal pollution index (HPI) of the water samples analyzed.
Table 3 presents results of HPI of water for both seasons. The mean HPI recorded in the study area for the wet and the dry seasons was 130 and 143 suggesting that the HPI for both seasons is within the category of high heavy metal pollution according to Sobhanardakania et al. (2016). This could be due to the presence of high concentrations of lead water. The HPI in the dry season was higher than HPI during the wet season indicating the effect of water supply in water quality in the region. The HPI results in this study are in line with the finding of Boateng et al. (2015) from Ejisu-Juaben Municipality, Ghana, but contrary to the finding of Eldaw et al. 2020, Singh and Kamal (2016), Mirza et al. (2020) and Maskooni et al. (2020) who reported HPI value less than 100 of underground water from North Kurdufan State, India, Bangladesh and southwest Iran, respectively.

\section{Relationship between the concentrations of heavy metals analyzed in the water}

The Pearson's product moment of correlation coefficient was used to determine the relationship between the concentrations of heavy metals in water during wet (Table 4) and dry season (Table 5). For correlation significance, the criteria value of probabilities $(p<0.05$ and $p<0.01)$ was used. There was a strong positive correlation between EC and TDS which implied that an increase in EC causes an increase in TDS showing a direct relationship between the variables. Similarly, strong negative correlation was observed between DO and BOD which implied that a decrease in DO results in an increase in BOD indicating some source of water pollution.

A strong positive correlation was established between $\mathrm{Se} /$ As during the wet season as well as $\mathrm{Se} / \mathrm{Hg}$ during the dry season suggesting an increase in one causes the other metal to increase. In addition, strong negative correlation was established between $\mathrm{Hg} / \mathrm{As}, \mathrm{Hg} / \mathrm{Cu}, \mathrm{Se} / \mathrm{Hg}, \mathrm{Se} / \mathrm{Pb}$ and $\mathrm{Zn} /$ $\mathrm{Hg}$ during wet season suggesting an increase in one causes the other metal to decrease.

Table 3 Heavy metals pollution index (HPI) of water sample in the water supply system

\begin{tabular}{|c|c|c|c|c|c|c|c|c|c|c|}
\hline \multirow[t]{2}{*}{ Heavy metals } & \multicolumn{2}{|c|}{$\begin{array}{l}\text { Mean con. }(\mu \mathrm{g} / \mathrm{L}) \text {, } \\
V_{i}\end{array}$} & \multirow[t]{2}{*}{$\begin{array}{l}\text { Standard value } \\
(\mu \mathrm{g} / \mathrm{L}), S_{i}\end{array}$} & \multirow[t]{2}{*}{ Unit weightage, $W_{i}$} & \multicolumn{2}{|l|}{ Subindex, $Q_{i}$} & \multicolumn{2}{|l|}{$Q_{i} \times W_{i}$} & \multicolumn{2}{|c|}{ Mean HPI } \\
\hline & Wet & Dry & & & Wet & Dry & Wet & Dry & Wet & Dry \\
\hline As & 3.33 & 3.21 & 10 & 0.1 & 33.3 & 32.1 & 3.33 & 3.21 & 130 & 143 \\
\hline $\mathrm{Cu}$ & 11.5 & NA & 2000 & 0.0005 & 0.575 & NA & 0.000288 & NA & & \\
\hline $\mathrm{Pb}$ & 47.67 & 53.06 & 10 & 0.1 & 476.7 & 530.6 & 47.67 & 53.06 & & \\
\hline $\mathrm{Se}$ & 0.22 & 0.12 & 40 & 0.025 & 0.55 & 0.3 & 0.0138 & 0.0075 & & \\
\hline $\mathrm{Zn}$ & 15.44 & 15.08 & 3000 & 0.00033 & 0.514667 & 0.502667 & 0.00017 & 0.00017 & & \\
\hline $\mathrm{Hg}$ & 0.042 & 0.03 & 6 & 0.16667 & 0.7 & 0.5 & 0.11667 & 0.08333 & & \\
\hline Sum & & & & 0.3925 & & & 51.1309 & 56.361 & & \\
\hline
\end{tabular}


Table 4 Pearson's correlation coefficient between the physicochemical properties and heavy metal concentration in water samples analyzed in the wet season

\begin{tabular}{|c|c|c|c|c|c|c|c|c|c|c|c|c|c|}
\hline & $\mathrm{pH}$ & $\mathrm{EC}$ & TDS & DO & BOD & Salinity & Temp & As & $\mathrm{Cu}$ & $\mathrm{Hg}$ & $\mathrm{Pb}$ & $\mathrm{Se}$ & $\mathrm{Zn}$ \\
\hline $\mathrm{pH}$ & 1.00 & & & & & & & & & & & & \\
\hline $\mathrm{EC}$ & 0.61 & 1.00 & & & & & & & & & & & \\
\hline TDS & 0.61 & 0.99 & 1.00 & & & & & & & & & & \\
\hline DO & -0.77 & -0.96 & -0.96 & 1.00 & & & & & & & & & \\
\hline BOD & 0.84 & 0.88 & 0.88 & -0.88 & 1.00 & & & & & & & & \\
\hline Salinity & 0.49 & 0.98 & 0.98 & -0.89 & 0.84 & 1.00 & & & & & & & \\
\hline Temp & -0.98 & -0.64 & -0.64 & 0.75 & -0.89 & -0.54 & 1.00 & & & & & & \\
\hline As & -0.66 & -0.43 & -0.43 & 0.39 & -0.79 & -0.43 & 0.78 & 1.00 & & & & & \\
\hline $\mathrm{Cu}$ & -0.34 & -0.50 & -0.50 & 0.64 & -0.20 & -0.41 & 0.19 & -0.42 & 1.00 & & & & \\
\hline $\mathrm{Hg}$ & 0.17 & 0.04 & 0.04 & 0.08 & 0.39 & 0.11 & -0.34 & -0.85 & 0.82 & 1.00 & & & \\
\hline $\mathrm{Pb}$ & 0.02 & 0.62 & 0.62 & -0.38 & 0.56 & 0.74 & -0.16 & -0.51 & 0.25 & 0.56 & 1.00 & & \\
\hline $\mathrm{Se}$ & -0.95 & -0.50 & -0.51 & 0.48 & -0.86 & -0.51 & 0.97 & 0.99 & -0.52 & -0.92 & -0.79 & 1.00 & \\
\hline $\mathrm{Zn}$ & -0.55 & -0.59 & -0.53 & 0.49 & -0.84 & -0.62 & 0.69 & 0.95 & -0.36 & -0.83 & -0.74 & 0.99 & 1.00 \\
\hline
\end{tabular}

Table 5 Pearson's correlation coefficient between physicochemical parameters and heavy metal concentration in water samples analyzed in the dry season

\begin{tabular}{|c|c|c|c|c|c|c|c|c|c|c|c|c|}
\hline & $\mathrm{pH}$ & $\mathrm{EC}$ & TDS & DO & BOD & Salinity & Temp & As & $\mathrm{Hg}$ & $\mathrm{Pb}$ & $\mathrm{Se}$ & $\mathrm{Zn}$ \\
\hline $\mathrm{pH}$ & 1.00 & & & & & & & & & & & \\
\hline $\mathrm{EC}$ & -0.56 & 1.00 & & & & & & & & & & \\
\hline TDS & -0.14 & 0.78 & 1.00 & & & & & & & & & \\
\hline DO & 0.04 & 0.24 & -0.22 & 1.00 & & & & & & & & \\
\hline BOD & -0.62 & 0.29 & 0.43 & -0.79 & 1.00 & & & & & & & \\
\hline Salinity & -0.97 & 0.39 & 0.04 & -0.22 & 0.72 & 1.00 & & & & & & \\
\hline Temp & 0.30 & 0.62 & 0.82 & 0.21 & -0.17 & -0.46 & 1.00 & & & & & \\
\hline As & 0.98 & -0.68 & -0.24 & -0.06 & -0.56 & -0.93 & 0.16 & 1.00 & & & & \\
\hline $\mathrm{Hg}$ & -0.44 & 0.32 & 0.59 & -0.84 & 0.97 & 0.54 & 0.04 & -0.41 & 1.00 & & & \\
\hline $\mathrm{Pb}$ & -0.13 & 0.46 & -0.03 & 0.97 & -0.64 & -0.08 & 0.31 & -0.24 & -0.68 & 1.00 & & \\
\hline $\mathrm{Se}$ & -0.75 & 0.16 & 0.13 & -0.68 & 0.94 & 0.87 & -0.46 & -0.67 & 0.83 & -0.56 & 1.00 & \\
\hline $\mathrm{Zn}$ & 0.13 & -0.86 & -0.98 & 0.01 & -0.26 & 0.01 & -0.88 & 0.26 & -0.41 & -0.19 & 0.02 & 1.00 \\
\hline
\end{tabular}

\section{Conclusion}

The physiochemical parameters of water samples from the region were within the WHO permissible limit for drinking water. There was seasonal effect on the physiochemical parameters of drinking water in the region with higher values recorded during the dry season compared to the wet except for $\mathrm{pH}$ and $\mathrm{DO}$ where higher values were recorded in the wet season. The concentration of the heavy metals in water was below the WHO standards except lead which exceeded the permissible limit. The concentration of heavy metals in water increases in the order of $\mathrm{Hg}<\mathrm{Se}<\mathrm{As}<\mathrm{Zn}<\mathrm{Cu}<\mathrm{Pb}$. The mean HPI recorded in the study for both seasons was above the critical index value of 100 , hence unfit for drinking.
Acknowledgements This research was funded by Office of Research, Innovation and Development, University of Ghana (URF/7/LMG005/20132014). Special thanks go to staff of the Department of Clinical Pathology, Noguchi Memorial Institute of Medical Research and Ecological Laboratory, University of Ghana, Messrs Prince Owusu and Emmanuel Ansah for their technical support. We are grateful to the Chief of Atuabo, District Chief Executives, Directors and Administrators of Shama, Sekondi-Takoradi, Ahanta West, Nzema East, Ellembelle and Jomoro and helpers in these districts for the cooperation and support.

Authors' Contribution OA, AOR., FMBY, OM, OAE, AD and NFKE designed the study, wrote the protocol and collected data. OA conducted data analysis and drafted the manuscript, All the authors reviewed and contributed to the writing of manuscript. FMBY is the corresponding author.

Funding This research was funded by Office of Research, Innovation and Development, University of Ghana (URF/7/LMG-005/20132014). 
Availability data and materials Data will be made available upon request.

\section{Declarations}

Conflicts of interest The authors declare that they have no conflicts of interest.

Ethical approval Permission was sought from the chiefs and elders of the communities before commencement of the study. The chiefs and elders were informed about the study, and their consent sought before data collection was conducted. Researchers and the community members contacted were not exposed to any form of psychological and physical risk.

Consent for publication All authors have agreed that the manuscript should be published.

Open Access This article is licensed under a Creative Commons Attribution 4.0 International License, which permits use, sharing, adaptation, distribution and reproduction in any medium or format, as long as you give appropriate credit to the original author(s) and the source, provide a link to the Creative Commons licence, and indicate if changes were made. The images or other third party material in this article are included in the article's Creative Commons licence, unless indicated otherwise in a credit line to the material. If material is not included in the article's Creative Commons licence and your intended use is not permitted by statutory regulation or exceeds the permitted use, you will need to obtain permission directly from the copyright holder. To view a copy of this licence, visit http://creativecommons.org/licenses/by/4.0/.

\section{References}

Adjei-Kyereme Y, Donkor AK, Golow AA, Yeboah PO, Pwamang J (2015) Mercuury concentrations in water and sediments in rivers impacted by artisanal gold mining in the Asutifi District, Ghana. Res J Chem Environ Sci 3(1):40-48

Amfo-Otu R, Omari S, Boakye-Dede E (2012) Assessment of physicochemical quality of groundwater sources in Ga East municipality of Ghana. Environ Nat Resour Res 2(3):19-24. https://doi.org/ 10.5539/enrr.v2n3p19

Apau J, Acheampong A, Bepule V (2014) Physicochemical and microbial parameters of water from hand-dug wells from Nyamebekyere, A Surburb of Obuasi, Ghana. Int J Sci Technol 3(6):347-351

APHA (2005) American public health association. Standard methods for the examination of water and wastewater, 21st edn. APHAAWWA-WEF, Washington

Bhattacharya P, Welch AH, Stollenwerk KG, McLaughlin MJ, Bundschuh J, Panaullah G (2007) Arsenic in the environment: biology and chemistry. Sci Total Environ 379(2-3):109-120. https://doi. org/10.1016/j.scitotenv.2007.02.037

Balakrishnan A, Ramu A (2016) Evaluation of heavy metal pollution index (HPI) of ground water in and around the coastal area of Gulf of Mannar biosphere and Palk Strait. J Adv Chem Sci 2(3):331-333

Boateng TK, Opoku F, Acquaah SO, Akoto O (2015) Pollution evaluation, sources and risk assessment of heavy metals in hand-dug wells from Ejisu-Juaben Municipality. Ghana Environ Syst Res $4: 18$
Chiamsathit C, Supunnika A, Thammarakcharoen S (2020) Heavy metal pollution index for assessment of seasonal groundwater supply quality in hillside area, Kalasin. Thail Appl Water Sci 10:142. https://doi.org/10.1007/s13201-020-01230-2

Dan SF, Umoh UU, Osabor VN (2014) Seasonal variation of enrichment and contamination of heavy metals in the surface water of Qua Iboe River Estuary and adjoining creeks, South-South Nigeria. J Oceanogr Mar Sci 5(6):45-54

Duruibe JO, Ogwuegbu MOC, Egwurugwu JN (2007) Heavy metal pollution and human biotoxic effects. Int J Phys Sci 2(5):112-118

Eldaw E, Huang T, Elubid B, Mahamed AK, Maham Y (2020) A Novel Approach for Indexing Heavy Metals Pollution to Assess Groundwater Quality for Drinking Purposes. Int J Environ Res Pub. Health 17:1245. https://doi.org/10.3390/ijerph17041245

Garg D, Kaur R, Chand D, Mehla SK, Singh RV (2008) Analysis of water quality of bharatpur area in post-monsoon season, January 2007. J Chem 1(4):743-750

Ghana Statistical Service (2010) 2010 Population and housing census: summary report of final results. Ghana Statistical Service, Accra

Gyamfi ET, Ackah M, Anim AK, Hanson JK, Kpattah L (2012) Chemical analysis of potable water samples from selected suburbs of Accra, Ghana. Int Acad Ecol Environ Sci 2(2):118-127

He ZL, Yang XE, Stoffella PJ (2005) Trace elements in agroecosystems and impacts on the environment. J Trace Elem Med Biol 19(2-3):125-140

Hsu P, Leon Y (2002) Antioxidant nutrients and lead toxicity. Toxicology 180:33-44

Kim MJ, Nriagu J, Haack S (2002) Arsenic species and chemistry in groundwater of southeast Michigan. Environ Pollut 120(2):379-390

Koffi KM, Coulibaly S, Atse BC, Paul E (2014) Survey of heavy metals concentrations in water and sediments of the estuary Bietri Bay. Ebrie Lagoon, Cote D ' Ivoire 1(3):1-10

Krishna AK, Govil PK (2004) Heavy metal contamination of soil around Pali industrial area, Rajasthan, India. Environ Geol 47(1):38-44

Manikannan R, Asokan S, Ali AHMS (2011) Seasonal variations of physico-chemical properties of the Great Swamp, Point Calimere Wildlife Sanctuary, South-east coast of India. Afr J Environ Sci Technol 5(9):673-681

Maskooni EK, Naseri-Rad M, Berndtsson R, Nakagawa K (2020) Use of heavy metal content and modified water quality index to assess groundwater quality in a semiarid area. Water 12:1115

Maughan RJ (1999) Role of micronutrients in sport and physical activity. Br Med Bull 55(3):683-690

Milivojević J, Krstić D, Šmit B, Djekić V (2016) Assessment of heavy metal contamination and calculation of its pollution index for Uglješnica River, Serbia. Bull Environ Contam Toxicol 97(5):737-774

Mirza ATM, Tanvir R, Moutushi P, Nikhil B, Mahmud H, Md. Khorshed A, Zakia A, (2020) Heavy metal pollution assessment in the groundwater of the Meghna Ghat industrial area, Bangladesh, by using water pollution indices approach. Appl Water Sci 10:186. https://doi.org/10.1007/s13201-020-01266-4

Mohan SV, Nithila P, Reddy SJ (1996) Estimation of heavy metals in drinking water and development of heavy metal pollution index. J Environ Sci Health A 31:283-289

Mohamed HM, Zahir HA (2013) Vedaranyam study of groundwater quality at Dindigul Town, Tamilnadu, India. International Research Jounrnal of Environment Science 2(1):68-73

Mukherjee A, Sengupta MK, Hossain MK, Ahamed S, Das B, Nayak B, Lodh D, Rahman MM, Chakraborti D (2006) Arsenic contamination in groundwater : a global perspective with emphasis on the Asian Scenario. J Health Popul Nutr 24(2):142-163 
Nkansah MA, Boadi MO, Badu M (2010) Assessment of the quality of water from Hand-Dug Wells in Ghana. Environmental Health Insights 4:7-12

Obodai EA, Boamponsem LK, Adokoh CK, Essumang DK, Villawoe BO, Aheto DW, Debrah JS (2011) Concentrations of heavy metals in two Ghanaian Lagoons. Arch Appl Sci Res 3(3):177-187. Retrieved from http://scholarsresearchlibrary.com/aasr-vol3-iss3/ AASR-2011-3-3-177-187.pdf

Oluyemi EA, Adekunle AS, Adenuga AA, Makinde WO (2010) Physico-chemical properties and heavy metal content of water sources in Ifane North local government area of Osun State, Nigeria. Afri J Environ Sci Technol 4(10):691-697

Peirce JJ, Vesilind PA, Weiner R (1998) Environmental pollution and control. Butterworth-Heinemann

Reza R, Singh G (2010) Assessment of ground water quality status by using Water Quality Index method in Orissa. India World Appl Sci J 9(12):1392-1397

Rizwan R, Gurdeep S, Manish KJ (2011) Application of heavy metal pollution index for ground water quality assessment in Angul District of Orissa. India Int J Res Chem Environ 1(2):118-122

Serfor-Armah Y, Nyarko BJB, Dampare SB, Adomako D (2006) Levels of arsenic and antimony in water and sediment from Prestea, A Gold Mining Town in Ghana and its Environs. Water Air Soil Pollut 175(1-4):181-192. https://doi.org/10.1007/ s11270-006-9127-9

Sharma B, Tyagi S (2013) Simplification of metal Ion analysis in fresh water samples by atomic absorption spectroscopy for laboratory students. J Lab Chem Edu 1(3):54-58. https://doi.org/10.5923/j. jlce. 20130103.04

Singh G, Kamal RK (2016) Heavy metal contamination and its indexing approach for groundwater of Goa mining region, India. Appl Water Sci 7:1479-1485
Sobhanardakania S, Yarib AR, Taghavic L, Tayebid L (2016) Water quality pollution indices to assess the heavy metal contamination, case study: groundwater resources of Asadabad Plain in 2012. Arch Hyg Sci 5(4):221-228

Umoren IU, Onianum PC (2005) Concentration and distribution of havy metals in urban soils of Ibadan, Nigeria Park. J Ind Res 48:297-401

WHO (1996) Guidelines for drinking-water quality, health and other supporting criteria, 2nd edn. World Health Organization, Geneva

World Health Organisation (WHO) (2011) Guidelines for drinking water quality: recommendations, 5th edn. WHO Press, Geneva, pp 45-76

WHO (2004) Guidelines for drinking-water quality, 3rd edn. World Health Organization, Geneva

Wilson B, Pyatt FB (2007) Heavy metal dispersion, persistance, and bioccumulation around an ancient copper mine situated in Anglesey, UK. Ecotoxicol Environ Saf 66(2007):224-231. https://doi. org/10.1016/j.ecoenv.2006.02.015

Yankey RK, Akiti TT, Osae S, Fianko JR, Duncan AE, Amartey EO, Agyemang O (2011) The hydrochemical characteristics of groundwater in the Tarkwa Mining Area, Ghana. Res J Environ Earth Sci 3(5):600-607

Zhang L, Wong MH (2007) Environmental mercury contamination in China: sources and impacts. Environ Int 33(1):108-121

Publisher's Note Springer Nature remains neutral with regard to jurisdictional claims in published maps and institutional affiliations. 